\title{
Stock market and economic growth nexus in Ghana
}

\author{
Samuel Antwi ${ }^{1}$, Mohammed Issah ${ }^{1}$ and Richard Kpodo ${ }^{2}$
}

\begin{abstract}
The aim of this study is to determine the role of monetary policy on the stock market and economic growth nexus in Ghana. The study used annual time series macroeconomic and stock market data from the year 1990 to 2019. Secondary data was collected on Gross Domestic Product (GDP), market capitalization (MC), Commercial bank (CB), inflation (INF), labour (L), capital stock (K), and trade openness (TO). Inflation was measured with consumer price index (CPI), and broad money (M2) were examined. The ARDL cointegration bounce test approach was used. It was revealed that stock market development has a significant positive effect on economic growth both in the short and long run. The study also found a support for a positive and significant nexus between monetary policy and economic growth. Based on the results it is suggested that efforts must be mounted to increase the number of firms to be listed to promote liquidity and raise the size of the market via capitalization ratio.
\end{abstract}

JEL classification numbers: 047, G1

Keywords: Stock Market, Economic Growth, Monetary Policy, Ghana

\section{Introduction}

The neo-classical growth model explains that every nation requires a better financial markets in order to foster rapid economic growth (Solow, 1956). This was explained in three ways; first, growth depends on capital accumulation (increasing the stock of capital goods to expand productive capacity). Secondly, net investment and the need for sufficient saving to finance investment through financial deepening may lead to growth and lastly, high savings that is postponing consumption to finance increased allocation of resources investment (Solow, 1956). Endogenous growth theory also believed that government policy would help increase capital and ensure investment in physical capital, which will then lead to an increase in economic growth (Romer, 1986; Lucas, 1988). This has cause most African countries to implement. Other empirical studies such as Shahbaz et al. (2008), Asante et al. (2011), Kapaya (2020) also believed that stock market impact economic growth. King and Levine (1993), Demirgue-Kunt and Maksimovic (1998), Levine, Loayza and Beck (2002), Ahmad and Malik (2009), Derk (2020), showed that broader, deeper financial markets are strongly associated with economic growth,

Despite the numerous benefits associated with stock market, Singh (1997) believed that stock market do not impact economic growth but rather such a market hamper economic growth due to their susceptibility to market failure, which is often showed in the uncertain nature of stock market in many developing countries. The volatility of stock market may decrease the capacity of the public to supervise the company's investment (Bhide, 1993). In addition, the public may increase investment returns by

\footnotetext{
${ }^{1}$ Department of Accounting, University of Professional Studies, Ghana

${ }^{2}$ Accra Business School, Ghana
}

Article Info: Received: May 7, $2021 \quad$ Published online: July 8, 2021 
speculating in the stock market; thus, the stock market development may be unfavourable to the economic growth. Obstfeld (1994) indicates that high financial market liquidity may increase investment returns and thus decrease saving rate due to substitution effect and income effect, which is unfavourable to economic growth. Naceur and Ghazouani (2007) also supported the claim of no relationship between stock market development and economic growth.

Although there are inconsistencies among these empirical studies, however these studies failed to examine the role of government policy on the relationship of stock market and economic growth as explained by neo- classical theory and endogenous theory. Based on this premise, the current study seeks to examine the role of the Ghana stock market on the economic growth in Ghana.

The key factor of the paper is to examine the effect of stock market development on economic growth in Ghana by evaluating the role of monetary policy on the stock market and economic growth nexus in Ghana. We submit that the current study is important for the following reasons. Stock market development plays an important role to develop the economy of the country. Stock market development achieved through stable macroeconomic variables gives credibility to the economy of a country to local and foreign trade partners. It was revealed that stock market development has a significant positive effect on economic growth both in the short and long run. The study also found a support for a positive and significant nexus between monetary policy and economic growth. The findings of the study support the literature and provide fresh insights into the relationship between stock market development and macroeco-nomic fundamentals which will assist central banks including the Bank of Ghana to monitor the effect of these macroeconomic variables on exchange rate. The study will assist Policy makers to get deeper understanding of the relation between macroeconomic variables and stock market development provides in budgeting for the various sectors of the economy and also to ensure its (the economy's) efficient performance.

\section{Literature review}

A study by Bayar, Kaya and Yildirim (2014) premised their examination on stock market developmenteconomic growth nexus in turkey. The study covered a period from 1999-2013. The Johannsen cointegration test was used to ascertain the long run nexus between stock market development and economic growth. Granger causality test was also run. The quantitative study documents a long run nexus between stock market development and economic growth in Turkey. Moreover, the granger causality test result confirmed a unidirectional between stock market development and economic growth.

Another study by Hoque and Yakob (2017) examine whether stock market development and economic growth nexus is contingent on the interacting role of capital inflows and exchange rate in Malaysia from 1981-2016. The examination is quantitative in analysis. The study deployed the granger causality and ARDL methodology. It was found that there exists unidirectional causality between stock market development and economic growth in Malaysia. The ARDL bound test result revealed that in the short and long run, stock market development promote economic growth.

On the other hand, Derk (2020) study premised on the stock market development and economic growth nexus. The study sourced quarterly time series data for 16 years from 2000-2018 on gross domestic product, exchange rate, and interest rate, total value of shares traded, and stock market capitalization. The study focus was to examine the impact of stock exchange market development on economic fortune in Malaysia. The Vector Error Correction Model and Granger causality test were used to examine the long and short run nexus of stock market development and economic growth. It was documented that there exists a bi-directional causal relationship between stock market development and economic growth. The Vector Error Correction Model result revealed an insignificant nexus between stock market development and economic growth. 
Another study by Rajabi and Muhammad (2014) specifically looked at the correlation between the stock market development and banking development on economic growth using panel data for ten Asian Islamic countries covering a period 1990-2009. The study tested the hypothesis that stock market development has a significant effect on economic growth in Asia. The examination was done using the dynamic pool panel mean-group methodology. The quantitative time series data was obtained for the examination. It was reported that stock market development and banks have a significant impact on economic growth.

A study focusing on African countries by Ngare, Nyamongo and Misati (2014) using panel data on 36 African countries, tested the hypothesis that stock market development has a significant effect on economic growth. The study is quantitative in approach, secondary time series annual data was sourced from 1980-2010. Panel data analysis was deployed. The empirical result revealed that economies with stock market strongly grow than economies without stock market. Also, economies which are more advanced turn to have their stock market more developed than economies that have small stock market.

Another study in africa by Kapaya (2020) on the causality of the stock market on economic growth using the ARDL approach. Secondary quarterly data was obtained covering 2001 to 2019 from Tanzania. The ARDL cointegration bounce test result revealed a long run nexus between stock market development and economic growth in Tanzania. The study observed that stock market development produced positive causality both for short and long run on economic growth. Economic growth is reported to trigger and correlate adversely to liquidity in the short and long run. The findings indicate that there exists a unidirectional causality between stock market development and economic growth. Partial causality was found between economic growth and stock market development, as measured a stock market turnover to determine liquidity.

On the other hand, Osamwonyi and Kasimu (2013) in their study, investigated if there is any causality between stock market development and economic growth in Ghana and Nigeria. The granger causality approach was used to ascertain the causal relationship for the period of 20 years. Secondary annual time series data was obtained from 1989-2009 on variables including stock market capitalization, stock turnover ratio, and stock traded value, number of listed securities, stock market index and gross domestic products. Gross domestic product proxied dependent variables while other variables served as the independent variables. The study revealed that there is absence of causality between stock market development and economic growth in Ghana and Nigeria. However, a bidirectional causality was found between stock market development and economic growth in Ghana. Market capitalization and listed securities were identified to granger cause economic growth when market capitalization was introduced to replace stock market in the model. Bidirectional causality was revealed between stock turnover and gross domestic product in the model. Moreover, stock traded value was observed to have a significant adverse nexus with gross domestic product.

Empirical arguments on stock exchange market development and economic growth nexus are inconclusive, some studies, reported positive and significant nexus while others found negative correlation and that economic growth is not contingent on the extent of the stock market development (Olweny \& Kimani, 2011).

In Ghana, Adusei (2014) using quarterly data on the Ghanaian economy assessed the effect of the stock market operation on economy growth from 2006-2013. The ARDL bound test, cointegration, granger causality and the Vector Error Correction Model was used for the analysis. The bound test results confirm a long run nexus between stock market operation and economic growth in Ghana. Moreover, the granger causality test result revealed a unidirectional causal relationship between stock market development and economic growth.

Another study in Ghana by Asamoah (2018) by using the Vector Error Correction Model method examined the long and short run stock exchange market development and economic growth nexus in Ghana. The quantitative study specifically seeks to ascertain the causal relationship between stock 
exchange market development and economic growth in Ghana. Monthly time series variables were collected from 2000-2012 to ascertain the long and short run nexus of stock exchange market development and economic growth. Series of econometrics tests were performed. The empirical examination confirmed that there exist a long and short run correlation between stock exchange market development and economic growth.

\section{Methodology}

\subsection{Data}

The data was collected from the website of Ghana Statistical Service (GSS), Ministry of Finance and Economic Planning (MoFEP), Bank of Ghana (BoG), Ghana Stock Exchange (GSE) and World Development Index (WDI). The data collected were first edited, coded and inputted into a statistical tool, Stata 15 for analysis.

\subsection{Model Specification}

For the purpose of the study, aggregate production function $\left(y_{t}\right)$ was used. The approach, based on an endogenous growth model, uses the Cobb-Douglas production function as used by (Klobodu \& Adams, 2016; Matuka \& Asafo, 2018; Rehman \& Ahmad, 2016; Nwosa \& Akinbobola, 2016), is given by:

$$
y_{t}=A_{t}^{a} K_{t}^{b} L_{t}^{c} \mathrm{e}^{\varepsilon_{t}}
$$

Where $y_{t}$ is real GDP at time $t$ and represent the output of the economy, $A_{t}, k_{t}$ and $L_{t}$ are respectively the productivity factor, the capital stock, and the labour stock at time t, $\varepsilon_{t}$ is the disturbance term and e is a base of natural logs.

On the assumption that technology is fixed, any increase in the amount of labor or capital will increase the output in the economy. In this case, A captures the productivity factor of growth in output which is not accounted for by an increase in labor and capital. Since this study seeks to investigate the effects of foreign capital on economic growth through changes in productivity factor, the productivity factor $\left(A_{t}\right)$ therefore is a function of foreign capital.

Commercial bank(CB) or commercial bank development is measured by the credit available to private sector.

$A_{t}$ is specified as;

$A_{t}=M C_{t} I N F_{t} C B_{t} M P_{t} T O_{t}$

Combination of equation (3.1) and (3.2) will give rise to (3)

$$
y_{t}=M C_{t}^{\vartheta} I N F_{t}^{\varphi} C B_{t}^{\sigma} M P_{t}^{\chi} T O_{t}^{P} K_{t}^{b} L_{t}^{c} \mathrm{e}^{\varepsilon_{t}}
$$

Where $\chi, \sigma, \vartheta, \varphi, b, c$ are constant elasticity coefficients of output relative to $\mathrm{K}, \mathrm{L}, \mathrm{CB}, \mathrm{INF}, \mathrm{GE}, \mathrm{TO}, \mathrm{MC}$ and $\varepsilon_{t}$ is the error term.

When natural log is taken on (3.3), it will result in (3.4)

$L n Y_{t}=\sigma L n M C_{t}+\vartheta L n I N F_{t}+\varphi L n C B_{t}+b L n K_{t}+\chi L n M P_{t}+c L n L_{t}+p L n T O_{t}+\varepsilon_{t}$

So (3.4) can be rewrite as

$$
\begin{aligned}
& L n Y_{t}=a+\sigma L n M C_{t}+\chi L n G E_{t}+\Omega\left(M C_{t} \times M P_{t}\right)++\vartheta L n I N F_{t}+\varphi L n C B_{t}+b \operatorname{Ln} K_{t}++p L n T O_{t}+ \\
& c \operatorname{Ln} L_{t}+\varepsilon_{t}
\end{aligned}
$$


$\chi \sigma, \vartheta, \Omega, \varphi, b, p, c$ are coefficients,

$Y_{t}=$ Annual GDP over time

$M C_{t}=$ stock market development

$C B_{t}=$ Commercial bank development over time

$I N F_{t}=$ Inflation over time

$K_{t}=$ Capital stock over time

$L_{t}=$ Labour Stock over time

$M P_{t}=$ Monetary Policy over time

$T O_{t}=$ Trade openness over time

$\varepsilon_{t}=$ Error term

\subsection{Estimation of ARDL Model}

To examine the effect of stock market on economic growth in Ghana, the study used the Bound Test Method developed by Pesaran and Shin (1999) and additionally extended by Pesaran, Shin and Smith (2001). This procedure is adopted because it is simple as opposed to other multivariate cointegration techniques such as the Johansen and Juselius (1990). The Bound Test allows the cointegration relationship to be estimated by OLS once the lag order of the model is identified. This approach is applicable regardless of whether the underlying regressors are purely stationary, purely integrated or mutually integrated. On the other hand, the Johansen and Julius approach to cointegration does not have good small sample properties and inevitably require a certain degree of pre-testing which further introduces another degree of uncertainty into the analysis (Pesaran et al., 2001). In addition, the Bound approach is considered essential as evidence of cointegrating relationship rules out the possibility of spurious regression. Another interesting fact about this model is that it can estimate long- run and shortrun components of model simultaneously (Narayan \& Narayan, 2006).

Furthermore, instead of imposing restrictions and deciding on the dependent variable, the Bound Test method distinguishes between dependent and independent variable through the usual F- tests. Moreover, as noted by Narayan (2004), the unrestricted equilibrium correction model is likely to have superior statistical properties compared to Engle-Granger method, as it does not push short- run dynamics into the residual terms (Pattichis, 1999; Banerjee et al., 1993; Banerjee et al., 1998). Thus, the superiority of the bound test approach to cointegration in terms of reducing efficient results for a relatively small sample study like this is assured. The study used Autoregressive Distributed Lag (ARDL) and for ARDL to be used, then the dependent variable should be a function of the independent variables and past values of the dependent variable. For the purpose of this study that is using annual time series data, a lag of the dependent variable will be added to function, now the model is specify as;

$\Delta \operatorname{Ln} Y_{t}=\alpha+\sum_{i=1}^{k} \Delta \Phi \operatorname{Ln} Y_{t-j}+\sum_{i=1}^{p} \Delta \beta^{\prime} \operatorname{Ln} X_{t-j}^{\prime}+\varepsilon_{i t}$

$\alpha=$ Intercept $\quad \varepsilon_{\mathrm{it}}=$ vector of Error term or unobserved variables

$X^{\prime}{ }_{t}=$ vector of independent variables which can either be I (0), I (1) or cointegrated

$\varphi, \beta=$ Coefficients

$Y^{\prime}{ }_{t}=$ vector of dependent variable

$K=$ is the optimal lags used for the dependent variable

$P=$ is the optimal lags for exogenous variables 
The method by Pesaran et al. (2001) necessitates the use of an Autoregressive Distributed Lag (ARDL) model to specify an Error Correction Model (ECM).

To estimate the both long and short dynamics of this study, ARDL was specified as;

$$
\begin{aligned}
& \Delta y_{t}=a+\sum_{t=1}^{q} \Delta \beta_{1} y_{t-1}+\sum_{t=1}^{k_{1}} \Delta \sigma L n M C_{t}+\sum_{t=1}^{k_{2}} \Delta \chi M P_{t}+\sum_{t=1}^{k_{3}} \Delta \Omega\left(M C_{t} \times M P_{t}\right)+\sum_{t=1}^{k_{4}} \Delta \chi M P_{t} \\
& +\sum_{t=1}^{k_{5}} \Delta \vartheta L n I N F_{t}+\sum_{t=1}^{6} \Delta \varphi \operatorname{LnCB_{t}}+\sum_{t=1}^{k_{7}} \Delta b \operatorname{LnK} K_{t}+\sum_{t=1}^{k_{8}} \Delta p L n T O_{t}+\sum_{t=1}^{k_{9}} \Delta c L n L_{t} \\
& +n E C T_{t-1}+\varepsilon_{t}
\end{aligned}
$$

Where;

$\mathrm{a}=$ the constant, $\Delta$ is the difference operator

$\chi \sigma, \vartheta, \varphi, b, p, c$ are coefficients,

$k_{1-7}$ are the optimal lags for the predictors

$P=$ is the optimal lags for exogenous variables

$E C T_{t-1}=$ Error Correction term

$\Delta=$ the difference operator

$Y_{t}=$ Annual GDP over time

$M C_{t}=$ Stock market development

$C B_{t}=$ Commercial bank development over time

$M C_{t} \times M P=$ The interaction term

$I N F_{t}=$ Inflation over time

$K_{t}=$ Capital stock over time

$L_{t}=$ Labour Stock over time

$M P_{t}=$ Monetary Policy over time

$T O_{t}=$ Trade openness over time

$\varepsilon_{t}=$ Error term

\section{Results and Discussion}

\subsection{Stationarity Test}

The stationarity test depends on the ADF and PP systems. The results of the unit root test are presented in Table 4.1 and 4.2. The ADF test and PP procedures involves testing the null hypothesis of nonstationarity of the variables against the alternative hypothesis of stationarity.

The ADF and PP tests accepted the existence of unit roots in the variables such as MC, $(M C \times M P), \mathrm{TO}, \mathrm{CB}, \mathrm{LAB}$ and $\mathrm{CAP}$ in their levels since the $\mathrm{t}$ - statistics small are than $\mathrm{t}$-critical for for both tests (ADF and PP) and the probabilities are more than 5\% for both test (ADF and PP) as well. This means that these variables are non-stationary. However, in the case of economic growth, inflation and monetary policy (MP), they happened to be stationary even at their level form. This is because both ADF 
and $\mathrm{PP}$ tests rejected the existence of unit roots meaning the $\mathrm{t}$ - statistics are greater than $\mathrm{t}$-critical for both tests (ADF and PP) and the probabilities are less than 5\% for both test (ADF and PP) as well.

Table 4.1: Stationarity Test- Level

\begin{tabular}{|c|c|c|c|c|c|c|c|}
\hline Variable & Lags & $\overline{\mathrm{ADF}}$ & & & PP & & \\
\hline & & T-statis & P-value & & T-statis & P-value & \\
\hline Growth & 1 & -3.363 & 0.0123 & $\overline{I I(0)}$ & -3.051 & 0.030 & I I (0) \\
\hline $\mathrm{MC}$ & 1 & -1.297 & 0.6306 & $\mathrm{I}(1)$ & -1.173 & 0.6850 & $\mathrm{I}(1)$ \\
\hline MP & 1 & -2.307 & 0.1696 & $\mathrm{I}(0)$ & -2.644 & 0.0371 & $\mathrm{I}(0)$ \\
\hline$(F D I \times E R V)$ & 1 & -1.427 & 0.5695 & $\mathrm{I}(1)$ & -1.326 & 0.6170 & $\mathrm{I}(1)$ \\
\hline INF & 1 & -3.678 & 0.004 & $\mathrm{I}(0)$ & -4.601 & 0.000 & $\mathrm{I}(0)$ \\
\hline TO & 1 & -2.043 & 0.2680 & I (1) & -1.756 & 0.4021 & I (1) \\
\hline LAB & 2 & 1.564 & 0.9977 & $\mathrm{I}(1)$ & 1.246 & 0.9963 & $\mathrm{I}(1)$ \\
\hline CAP & 2 & -1.940 & 0.313 & $\mathrm{I}(1)$ & -1.634 & 0.4654 & I (1) \\
\hline $\mathrm{CB}$ & 1 & -3.048 & 0.030 & $\mathrm{I}(1)$ & -5.260 & 0.0000 & I (1) \\
\hline
\end{tabular}

Source: Field Study, 2020

The establishment of relationships is very important in macroeconomic analysis, therefore when variables are non-stationary, they tend to produce unrelated regressions or spurious relationships. An important step to making non-stationary variables stationary is by differencing them. The results in table 4.2 showed that all variables for the study are stationary at their first differences since all the probabilities are less than $5 \%$. This means that the variables are free from unit root problem in their first differences. This way, when a regression is run on these variables, no spurious outcomes are expected. In other words, the variables are integrated of order one-they are I (1) processes. Based on the above findings, the precondition for the cointegration test by Pesasaran et al. (2001) is satisfied for the study. 
Table 4.2: Stationarity Test- First Difference

\begin{tabular}{|c|c|c|c|c|c|c|c|}
\hline Variable & Lags & ADF & & & PP & & \\
\hline & & $\begin{array}{l}\mathrm{T}- \\
\text { statistics }\end{array}$ & P-value & & T-statistic & P-value & \\
\hline Growth & $\bar{~} 1$ & -5.916 & 0.0000 & I I (0) & "-7.067 & 0.0000 & I I (0) \\
\hline MC & 1 & -4.386 & 0.0000 & $\mathrm{I}(0)$ & -5.010 & 0.0000 & $\mathrm{I}(0)$ \\
\hline MP & 1 & -6.173 & 0.0000 & $\mathrm{I}(0)$ & -8.713 & 0.0000 & $\mathrm{I}(0)$ \\
\hline$(M C \times M P)$ & 1 & -3.197 & 0.0201 & $\mathrm{I}(0)$ & -5.294 & 0.0000 & $\mathrm{I}(0)$ \\
\hline INF & 1 & -6.421 & 0.0000 & $\mathrm{I}(0)$ & -14.311 & 0.0000 & $\mathrm{I}(0)$ \\
\hline TO & 1 & -5.753 & 0.0000 & $\mathrm{I}(0)$ & -5.981 & 0.0000 & $\mathrm{I}(0)$ \\
\hline $\mathrm{Lab}$ & 2 & -2.579 & 0.0450 & $\mathrm{I}(0)$ & -10.021 & 0.0000 & $\mathrm{I}(0)$ \\
\hline CAP & 2 & -3.048 & 0.030 & $\mathrm{I}(0)$ & -5.260 & 0.0000 & $\mathrm{I}(0)$ \\
\hline $\mathrm{CB}$ & 1 & -2.048 & 0.032 & $\mathrm{I}(0)$ & -5.320 & 0.0000 & $\mathrm{I}(0)$ \\
\hline
\end{tabular}

Source: Field Study, 2020

\subsection{Cointegration Test}

The underlying advance in the ARDL approach is to assess the least square conditional VECM to test whether there are long run relationship between the variables (Pesaran, et al. 2001). This is finished by performing an $\mathrm{F}$ test for the joint significance of the lagged level coefficients of the variables. Therefore, every one of the variables in the model is taken as a dependent variable and a regression is applied to the others. This F-statistic examines the joint null hypothesis that there is no long run relationship between the variables.

I (0) is the value for the lower bounds test whereas I (1) is the value for the upper bounds test and can be accepted 1 to $10 \%$ significant level (Pesaran, et al. 2001). The results of the F calculated when each variable is normalized (that is, considered as a dependent variable) in the ARDL-OLS regressions are shown in the table below. In table 4.3, growth was used as dependent in different scenario; growth was dependent variable when there was an interaction term, growth was also the dependent variable when only stock market development (MC) was the main independent variable of interest and growth was used as dependent when only monetary policy (MP) was the main independent variable of interest. 
Table 4.3: Cointegration Test

\begin{tabular}{|c|c|c|c|c|c|c|c|c|}
\hline \multirow[t]{2}{*}{ Model } & \multicolumn{2}{|c|}{ F- statistics (k) } & \multicolumn{2}{|c|}{$90 \%$} & \multicolumn{2}{|c|}{$95 \%$} & \multicolumn{2}{|c|}{$99 \%$} \\
\hline & & & 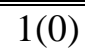 & $1(1)$ & $\overline{l 1(0)}$ & 1(1) & $1(0)$ & (1(1) \\
\hline Interaction & 6.743 & $(8)$ & 2.03 & 3.13 & 2.32 & 3.50 & 2.96 & 4.26 \\
\hline MC-Growth & 11.550 & $(6)$ & 2.26 & 3.35 & 2.62 & 3.79 & 3.41 & 4.68 \\
\hline MP- Growth & 11.978 & (6) & 2.26 & 3.35 & 2.62 & 3.79 & 3.41 & 4.68 \\
\hline
\end{tabular}

(K) is the number of predictors

Source: Field Study, 2020

The F-statistic estimated for all the three equations are greater than the upper bounds, which means all of them were even significant at $1 \%$. The null hypothesis of no cointegration is reject against alternative for all three equations. This means that these variables are cointegrated. By implication, all the variables converge in the long run. Once, there is cointegration, ARDL with ECM are estimated.

\subsection{The effect of Stock Market Development on Economic Growth}

\subsubsection{Long Run Effects}

From Table 4.4 below, it was identified that stock market development (MC) has a positive significant effect on economic growth (Growth) in Ghana. The coefficient of 3.25452\% means that holding other factors constant, a percentage increase in the development of stock market will induce economic growth by approximately $3.25 \%$. By implication, when better efforts are put in place to enhance the development of stock market, economic growth will automatically improve. This result therefore corroborate with the study of Asante et al. (2011) who believed that development of stock market increases economic growth and development. Similar results were obtained by Enisan and Olufisayo (2009), Ngare, Nyamongo and Misati (2014) who argue that when there is a well-developed stock market, it accumulate funds for investments which then induces economic growth. However, the findings was against the study of Olweny and Kimani (2011) and (Derk, 2020) who concluded that inefficiency of the stock market hamper economic growth and development.

Result from Table 4.4 shows that Commercial bank(CB) which was measured with credit available to private sector has a positive effect on economic growth with a coefficient of $4.25612 \%$ and significant at $1 \%$. This implies that a percentage increase in Commercial bank in Ghana will lead to an improvement of the economic growth. This is because when private firms get access to funds, they are able to invest which affect economic growth. This confirms the study of Boon (2002) which stated that in the loan market, there is always demand of loan which has affected investment level, thus increase in economic growth.

In the long run, labour was seen to have a positive significant effect on economic showing a coefficients of $3.24812 \%$ at 5\% significant level as shown in Table 4.4. This therefore agrees with the Neo-classical theory, which stipulate that labour is a great determinant of growth (Solow, 1957). The study confirms with the findings of the following empirical studies; Rehman and Ahmad (2016), Antwi and Koranteng (2017), Adenutsi (2011) who showed that labour force assumes a significant role in the advancement of the economy. However the result is contradicted by the study of Fambon (2013) who concluded that Cameroon, like most developing SSA countries is characterized by an unlimited supply of labour, thus it impact on economic growth wont be felt. Frimpong and Oteng-Abayie (2006) and Sakyi (2011) also 
conducted a study in Ghana and identified a negative effect of labour on economic growth. Their result disagree with the current study.

Table 4.4 revealed that domestic capital had a positive significant effect on economic growth in Ghana. The attained coefficient of 2.63254 suggest that a percentage increase in domestic capital will to approxitely $2.63 \%$ increase in economic growth. This could be the benefit derived from the stock market development since stock maket provide and efficiently allocate capital for investment (Boon, 2009). Therefore it was expected to have a positive effect as explained by Solow (1957) in the neo-classical theory. The finding is line with the findings of Shaheen, Ali, Kauser and Bashir (2013); Falki (2009); and Khan and Qayum (2007). It is also consistent with conclusions reached by Ibrahim (2011) and Asiedu (2013) in the case of Ghana. Ibrahim (2011) and Asiedu (2013) found positive and statistically significant effect of capital on economic growth for Ghana. It is consistent with conclusions reached by Aryeetey and Fosu (2003); and Fosu and Magnus (2006) in the case of Ghana. However, it was identified that inflation and trade openness had no effect on economic growth in Ghana from 1990 to 2018.

Table 4.4: Long Run Effects of Stock Market Development- Economic Growth Nexus

\begin{tabular}{lllll}
\hline \hline Variables & Coefficient & Std. Error & T-Statistics & P-Values \\
\hline \hline MC & $3.25452 * * *$ & 1.21534 & 15.1134021 & 0.000 \\
CB & $4.25612^{* * *}$ & 0.103409 & 41.1579605 & 0.000 \\
INF & -2.45215 & 2.152652 & -1.13912978 & 0.125 \\
TO & 2.31254 & 1.512588 & 1.52886311 & 0.215 \\
LAB & $3.24812^{* *}$ & 1.12582 & 2.88511485 & 0.020 \\
CAP & $2.63254 * * *$ & 0.12524 & 21.0199617 & 0.000 \\
\hline \hline
\end{tabular}

Source: Field Study, 2020

\subsubsection{Short Run}

From Table 4.5 below, only the lag of growth, inflation and trade openness were seen to have statistically significant effect on economic growth, meaning these variables alone can predict economic growth in the short run. The negative sign of error correction term shows the convergence of the variables in the longrun and is statistically significant at $5 \%$ significance level. The coefficient of the ECM (-1) is equal to ($0.25615 \%$ ) for short-run model which shows that deviation from short-run in economic growth is corrected by $0.26 \%$ on each year in the long-run. The negative sign of the adjustment coefficient also confirms the existence of cointegration between the variables. The rule of thumb is that, the greater the error correction coefficient (in absolute terms), the faster the variables adjust back to the long-run equilibrium when shocked (Acheampong, 2007) and therefore shows that the adjustment in the study in restoring equilibrium following a shock is quite swift

The lag of economic growth (growth-1)) had a significant positive effect on the current economic growth (Growth) with a coefficient of 5.21358\% at 5 percent significant level as displayed in Table 4.6. The coefficient of 5.2\% suggest that a percentage increase in the former economic growth will affect the current economic growth by 5.2 percent, all things being equal. This result actually confirms the findings of (Antwi, Mills, Mills, \& Zhao, 2013) who also included the previous growth as a control variable and had a significant value it. The findings in Table 4.5 suggest that inflation has negative influence on economic growth and it is statistically significant at $5 \%(\mathrm{p}=0.026<0.05)$. The expected sign of this variable was revealed, which means in a high inflationary period, firms face uncertainty in terms of product and input pricing, and thus investors may limit the amount of resources invested in such 
economies. The coefficient of openness to trade was $1.701588 \%$, which means that, a percentage increase in trade openness will result in approximately $1.71 \%$ increment in GDP, all things being equal. According to economic theory, trade induces economic growth by enhancing capital formation and efficiency, and by increasing the supply of scarce resources. For Ghana, the results obtained suggests that the trade openness policy adopted as part of the structural reforms in the 1980 in Ghana has impacted growth. This seem to support the notion that emphasizes the fact that trade openness enhances competition and efficiency as well as transfer of technology and knowledge and hence enhancing growth. The results is against the findings of Ali \& Abdullah, 2015. The findings by Ali and Abdullah (2015) showed a negative and statistically significant long-run relationship between trade openness and economic growth for Pakistan. Githanga (2015) on the other hand also found a negative and statistically significant long-run relationship between trade openness and economic growth for Kenya implying that trade openness is growth hampering in the long-run in Kenya. The results obtained in this study in the long run does not absolutely resolve the conflicting results in the extant literature but contribute to the controversy in the literature by aligning itself with those studies such as Edwards (1993); Nduka, Chukwu, Ugbor and Nwakaire (2013); and Ayibor (2012) which believe that trade openness positively affects GDP growth. Moreover, Edwards (1993), Sachs and Warner (1995), Nduka et al. (2013); and Hamad, Mtengwa and Babiker (2014) who found a positive impact of trade openness on economic growth.

The summary statistics in Table 4.5 showed that whole model (both short run and long) has a great predicting power of $79.07 \%$ and it is significant at $5 \%$. This means that $79.07 \%$ variation in the dependent variable (economic growth) can be explained by the variation in the dependent variables such as stock market development, commercial bank development, inflation, trade openness, human capital and the domestic capital. The model is free of issues including the serial correlation, the heteroscedasticity, and normality as presented in the table above, since all the test fails to reject the null hypothesis.

Table 4.5: Short Run Effects

\begin{tabular}{lllll}
\hline \hline Variables & Coefficient & Std. Error & T-Statistics & P-Values \\
\hline \hline Ecm & $-0.25615^{* *}$ & 0.078523 & -3.26210155 & 0.011 \\
Growth & $5.213548^{* *}$ & 2.21534 & 2.35338503 & 0.020 \\
D(FD) & 1.201254 & 0.803409 & 1.49519535 & 0.115 \\
D(INF) & $-3.21645^{* * *}$ & 0.15265 & -21.0707632 & 0.000 \\
D(TO) & $1.701588^{* *}$ & 0.613409 & 2.77398423 & 0.021 \\
D(LAB) & 2.125823 & 1.502156 & 1.41518125 & 0.126 \\
D(LAB $(-1))$ & 3.212545 & 1.763548 & 1.8216372 & 0.032 \\
D(CAP) & 1.72658 & 2.12524 & 0.81241648 & 0.321 \\
D(CAP(-1)) & 3.01258 & 1.73555 & 1.73580709 & 0.111 \\
\hline \hline R-squared & & 0.7907 & F-statistic & 28.844120 \\
Adjusted R-squared & 0.7511 & Prob(F-statistic) & 0.000 \\
DW-statistics & & 0.22154 & Arch effect & 0.1345 \\
Normality & & 0.22154 & & \\
\hline \hline
\end{tabular}

**, *** means significant levels at $10 \%, 5 \%$ and $1 \%$

Source: Field Study, 2020 


\subsection{The Effect of Monetary Policy on Economic Growth}

The results are shown in Table 4.6 and Table 4.7 All the variables in the Table 4.6 and Table 4.7 are log transformed.

In the long run, monetary policy (MP), commercial bank development and domestic capital had significant effect on economic growth as shown in table 4.6. For instance, MP had $4.295952 \%$ as a coefficient having significant effects on economic growth. This means a percentage increase in monetary policy of an economy like Ghana will increase its economic growth by $4.3 \%$ approximately, all things being equal. This suggest that when monetary policy represented by money supply increases, there will be more money in circulation, which will enhance investors to gain access to funds, invest these into capital project, hence inducing economic growth (Onyeiwu 2012). This agrees with the findings of Chaudhry et al. (2012), Mugume (2011), Jawaid et al. (2011), Ogunmuyiwa and Ekone (2010) and among others who identified positive impact on economic growth.

However, the result disagrees with the study of Amarasekara (2009), Buigut (2009) who concludes that, monetary policy hamper economic growth.

In addition, Table 4.6 revealed that commercial bank development (CB) has a positive effect on economic growth and it is statistically significant at $1 \%$. The coefficient of $5.125288 \%$ means that average ceteris paribus, a perecentage increase in the development of commercial bank will increase economic growth by approximately $5.13 \%$. However, the exclusion of stock market development and replacement of monetary policy, had increase the effect commercial bank development on economic growth. Comparing Table 4.6 to Table 4.5 suggest a vital increase in the coefficient that is Table 4.5 has a coefficient of $4.25612 \%$ whereas Table 4.6 has $5.125288 \%$. This means that monetary policy is an important in determining the success of financial development in economies such as Ghana (Boon, 2009).

Lastly, domestic capital (CAP) showed a positive impact on economic growth (Growth) with a coefficient of $2.63254 \%$ at $1 \%$ significant level. This suggest that $1 \%$ increase in CAP will result in approximately $2.63 \%$ increase in Growth. By implication, when there is sound monetary policy, it will help development financial sector which also affect the domestic capital and private investment. This result also corroborate with the neo-classical theory where growth is a function of capital and other factors (Solow, 1957).

Table 4.6: Effect of Monetary Policy on Economic Growth

\begin{tabular}{lllll}
\hline \hline Variables & Coefficient & Std. Error & T-Statistics & P-Values \\
\hline \hline MP & $4.295952 * * *$ & 0.157122 & 27.3415053 & 0.000 \\
CB & $5.125288 * * *$ & 0.103409 & 49.5630765 & 0.000 \\
INF & -2.45222 & 2.152652 & -1.13915998 & 0.125 \\
TO & 2.312514 & 1.512588 & 1.52884592 & 0.181 \\
LAB & 0.215881 & 1.12582 & 0.19175445 & 0.172 \\
CAP & $2.63254 * * *$ & 0.12524 & 21.0199617 & 0.000 \\
\hline
\end{tabular}

*** means significant levels at $1 \%$

Source: Field Study, 2020

From Table 4.7 below, the parsimonious result of the Error Correction Term (that is ECT (-1)) on the effects of monetary policy on economic growth. The ECM coefficient showed the speed of adjustment from the short-run towards the long-run equilibrium. The ECM is expected to be negatively signed and statistically significant. A highly significant ECM coefficient proves the existence of a stable long-run 
relationship (Banerjee \& Newman, 1993). From the parsimonious estimate, the coefficient of the error correction term was correctly negatively signed $(0.35615 \%)$ and statistically significant as observed from table 4.7. The coefficient estimates of the error correction term of 0.35 implied that the model corrects its short-run disequilibrium by 0.35 per cent speed of adjustment in order to return to the long-run equilibrium.

The lag of economic growth (growth-1) had a significant positive effect on the current economic growth (Growth) with a coefficient of 5.21358\% at 5 percent significant level as displayed in Table 4.5. The coefficient of $5.2 \%$ suggest that a percentage increase in the former economic growth will affect the current economic growth by 5.2 percent, all things being equal. This result actually confirms the findings of (Antwi, Mills, Mills, \& Zhao, 2013) who also included the previous growth as a control variable and had a significant value it.

In table 4.7, it can be seen that inflation (INF) had the expected microeconomic theory sign of negative. It can be said that inflation in the short run had a negative effect on economic growth in Ghana. By implication as INF increases a percent, economic growth increases by $4.21645 \%$. This is when money supply increases; more money will be used to chase few commodity which will then causes persistant increase in the general price of goods and services (Mugume, 2011; Jawaid et al., 2011). Also, a high inflationary period, firms face uncertainty in terms of product and input pricing, thus investors may limit the amount of resources invested in such economies (Sneider \& Frey, 1985).

The coefficient of openness to trade was $1.701588 \%$, which means that, a percentage increase in trade openness will result in approximately $1.71 \%$ increment in GDP, all things being equal as shown in Table 4.7. This confirming to what the theory posits since trade is assumed to be growth enhancing. International trade leads to specialization and exchange which broadens the productivity base of a nation. Thus, an increase in the productivity base of a country tends to boost economic growth. From Keynesian's principle, high net export (trade openness) increases national income which eventually increases growth in the economy

Table 4.7 showed that the whole model (both short run and long) has a great predicting power of $72.41 \%$ and it is significant at $5 \%$. This means that $72.41 \%$ variation in the dependent variable (economic growth) can be explained by the variation in the dependents variables. Also, a DW-statistics of 2.102 reveals that there is no autocorrelation in the residuals. Since the $p$-value $(0.1423)$ is more than 5 percent $(p>0.05)$, we fail to reject null hypothesis of homoskedasticity meaning the output is not suffering from heteroskedasticity (the variance of expected error term condition on the independent variables is constant).

Table 4.7: Short Run Effects

\begin{tabular}{lllll}
\hline \hline Variables & Coefficient & Std. Error & T-Statistics & P-Values \\
\hline \hline ECT (-1) & $-0.35615^{* * *}$ & 0.078523 & -4.53561377 & 0.001 \\
Growth & $3.213548 * * *$ & 0.21534 & 14.9231355 & 0.000 \\
$\mathrm{D}(\mathrm{FD})$ & 1.201254 & 0.803409 & 1.49519535 & 0.215 \\
$\mathrm{D}(\mathrm{INF})$ & $-4.21645 * *$ & 0.85265 & -4.94511464 & 0.001 \\
$\mathrm{D}(\mathrm{TO})$ & $3.125782^{* * *}$ & 0.613409 & 5.09575171 & 0.000 \\
$\mathrm{D}(\mathrm{LAB})$ & 2.125823 & 1.502156 & 1.41518125 & 0.156 \\
$\mathrm{D}(\mathrm{LAB}(-1))$ & 3.212545 & 1.763548 & 1.8216372 & 0.111 \\
\hline \hline
\end{tabular}




\begin{tabular}{lllll}
\hline \hline $\mathrm{D}(\mathrm{CAP})$ & 1.72658 & 2.12524 & 0.81241648 & 0.131 \\
$\mathrm{D}(\mathrm{CAP}(-1))$ & 3.01258 & 2.73555 & 1.10127031 & 0.125
\end{tabular}

\begin{tabular}{lclc}
\hline \hline R-squared & 0.7241 & F-statistic & 28.864120 \\
Adjusted R-squared & 0.7069 & Prob(F-statistic) & 0.0020 \\
DW-statistics & 2.102 & Arch effect & 0.1423 \\
Normality & 0.22514 & & \\
\hline \hline
\end{tabular}

**, *** means significant levels at 10\%, 5\% and 1\%

Source: Field Study, 2020

The long run results from Table 4.8 below, Broad money is used to proxy for monetary policy. This variable is interacted with the variable of interest (stock market development). The long run relationship of the interacting term revealed a positive nexus between stock market development and monetary policy (broad money). Confirming that on average, $1 \%$ increase improvement in monetary policy will lead to $1.86 \%$ increase in stock market development and economic growth holding other factors same and this is statistically significant at $1 \%$. Stock market development nexus with economic growth is found be positive (2.933945). This is statistically significant at 5\%. It therefore sounds to reason that the of presence robust monetary policy significantly promote the extent of effectiveness of the stock market development, leading to strong nexus between stock market development on economic growth.

Table 4.8: Long Run Relationship of the Interaction term

\begin{tabular}{lllll}
\hline & Coefficients & Std. Deviation & T-statistics & P-Value \\
\hline MC & $2.933945^{* *}$ & 1.1554521 & 2.539223 & 0.020 \\
MP & $4.295952^{* * *}$ & 0.1527122 & 27.34147 & 0.000 \\
FD & $2.125155^{* *}$ & 0.6284821 & 3.38142 & 0.018 \\
INF & $-1.45215^{* * *}$ & 0.1526512 & -9.512938 & 0.001 \\
TO & 0.0721462 & 0.1034094 & 0.697675 & 0.215 \\
LAB & 0.172146 & 0.1234090 & 1.39492 & 0.111 \\
CAP & $1.2154^{* *}$ & 0.3155502 & 3.851688 & 0.016 \\
$M C_{t} \times M P$ & 1.86125 & 0.1255021 & 14.83043 & 0.000 \\
\hline
\end{tabular}

The short run results from Table 4.9 below, also confirmed that the short run relationship of the interacting term in positive, indicating that on average 1\% increase in monetary policy will lead to $3.12 \%$ increase in the development of the stock market, hence impacting positively on economic growth in Ghana holding other factor constant. This is statistically significant at $10 \%$. 
Table 4.9: Short Run Relationship of the Interaction term

\begin{tabular}{|c|c|c|c|c|}
\hline & Coefficients & Std. Deviation & T-statistics & P-Value \\
\hline$\overline{\mathrm{ECT}(-1)}$ & $-0.231452 * *$ & 0.1124510 & -2.05824 & 0.030 \\
\hline $\mathrm{D}($ Growth $(-1))$ & 2.6033443 & 0.804768 & 3.24 & 0.007 \\
\hline $\mathrm{D}(\mathrm{MC})$ & 3.15248 & 2.21534 & 1.4230231 & 0.312 \\
\hline $\mathrm{D}(\mathrm{MP})$ & 1.248245 & 1.152712 & 1.08287654 & 0.213 \\
\hline $\mathrm{D}(\mathrm{FD})$ & 0.062723 & 0.103409 & 0.60655027 & 0.215 \\
\hline $\mathrm{D}(\mathrm{INF})$ & $-2.45215 * * *$ & 0.15265 & -16.0638716 & 0.000 \\
\hline $\mathrm{D}(\mathrm{TO})$ & 2.157156 & 1.013409 & 2.12861258 & 0.215 \\
\hline $\mathrm{D}(\mathrm{LAB})$ & 3.24812 & 1.82456 & 1.78022098 & 0.125 \\
\hline $\mathrm{D}(\mathrm{LAB}(-1))$ & $2.152401 * *$ & 1.023409 & 2.10316794 & 0.021 \\
\hline $\mathrm{D}(\mathrm{CAP})$ & 3.12458 & 2.12524 & 1.47022454 & 0.132 \\
\hline $\mathrm{D}(\mathrm{CAP}(-1))$ & 2.01258 & 1.31555 & 1.52983923 & 0.132 \\
\hline$M C_{t} \times M P$ & $3.125424 *$ & 1.81255 & 1.72432429 & 0.078 \\
\hline R-Squared & 0.7982 & \multicolumn{2}{|c|}{ F-Statistic } & 28.8424 \\
\hline Adjusted R-Squared & 0.7125 & \multicolumn{2}{|c|}{ Prob (F-Statistics) } & 0.000 \\
\hline DW-Statistics & 2.105 & \multicolumn{2}{|c|}{ Arch Effect } & 0.2245 \\
\hline Normality & 0.62154 & & & \\
\hline
\end{tabular}

\section{Conclusion}

The aim of this study was to examine the effect of stock market development on economic growth in Ghana. The study used an annual time series from the year 1990 to 2019 due to the availability of data. In the long run, monetary policy (MP), commercial bank development and domestic capital had significant effect on economic growth. Moreover, it was identified that stock market development (MC) has a positive significant effect on economic growth (Growth) in Ghana. By implication, when better efforts are put in place to enhance the development of stock market, economic growth will automatically improve. The study concludes that all variables of interest (MC, CB, INF, LAB and CAP) with the exception of (TO) were significant in explaining economic growth in Ghana. The study also concludes that monetary policy had a significant impact on economic growth. Finally, the interacting term of capital market development and monetary policy has a significant positive effect on economic growth. One of the key contribution of our study is our empirical findings on an active stock market channel of monetary policy on economic growth in Ghana.

Since stock market development is found to have a positive and significant effect on economic growth, it is recommended that efforts must be mounted to increase the number of firms to be listed to promote liquidity and raise the size of the market via capitalization ratio. It is also suggested that the central government must use workable monetary policy in a form of tax reforms to attract more potential investors on the stock market. It is also imperative to mention that, the central government through the central bank must reduce the interest payment on risk free assets like the treasure bills and government securities (bonds) to motivate potential investors scouting for higher yields. 
Future examination on stock market and economic growth nexus in Ghana can use quarterly data rather than annual data to generate bigger data points and ascertain how the nexus observed here will differ. Other stock market determinants, including turnover ratio, total value traded and number of new listing can be looked at for further examination.

\section{References}

Adusei, M. (2014). Does stock market development promote economic growth in Ghana? International journal of economics and finance, 6(6), 119-126

Antonios, A. (2010). Stock Market and Economic Growth: An Empirical Analysis for Nigeria. Business and Economics Journal, 1-12. https://doi.org/10.2139/ssrn.3402423

Asante, S., Agyapong, D., \& Adam, A. M. (2011). Bank Competition, Stock Market and Economic Growth in Ghana. International Journal of Business Administration, 2(4), 33-41. https://doi.org/10.5430/ijba.v2n4p33

Asamoah, G. (2018). Impact of Ghana Stock Exchange Development on Economic Growth: A Robust Time Series Econometric Analysis. Interdisciplinary Research Journal of Theology, Apologetics, Natural and Social Sciences, Vol.1, No.1\&2.

Akinlo, O. O. (2014). Oil price and stock market: Empirical evidence from Nigeria. European Journal of Sustainable Development, 3(2), 33-33.

Alajekwu, U. B., Ezeabasili, V. N., \& Nzotta, S. M. (2013). Trade openness, stock market development and economic growth of Nigeria: Empirical evidence. Research Journal of Finance and Accounting, 4(3), 120-127.

Bayar, Y., Kaya, A., \& Yildirim, M. (2014). Effects of stock market development on economic growth: Evidence from Turkey. International Journal of Financial Research, 5(1), 93.

Bjørnland, H. C., \& Leitemo, K. (2009). Identifying the interdependence between US monetary policy and the stock market. Journal of Monetary Economics, 56(2), 275-282.

Christiano, L., Ilut, C. L., Motto, R., \& Rostagno, M. (2010). Monetary policy and stock market booms (No. w16402). National Bureau of Economic Research.

Derk, N. (2020). Stock Market and Economic Performance in Malaysian Context. Finance \& Accounting Research Journal, 2(2), 82-90.

Enisan, A. A., \& Olufisayo, A. O. (2009). Stock market development and economic growth: Evidence from seven sub-Sahara African countries. Journal of economics and business, $\quad 61(2), 162-171$.

Hoque, M. E., \& Yakob, N. A. (2017). Revisiting stock market development and economic growth nexus: The moderating role of foreign capital inflows and exchange rates. Cogent Economics \& Finance, 5(1), 1329975.

Kapaya, S. M. (2020). Stock market development and economic growth in Tanzania: an ARDL and bound testing approach. Review of Economics and Political Science.

Ngare, E., Nyamongo, E. M., \& Misati, R. N. (2014). Stock market development and economic growth in Africa. Journal of Economics and Business, 74, 24-39.

Nzomoi, J. N., \& Ikikii, S. M. (2013). An analysis of the effects of stock market development on economic growth in Kenya.

Onyeiwu, C. (2012). Monetary policy and economic growth of Nigeria. Journal of Economics and Sustainable development, 3(7), 62-70.

Olweny, T. O., \& Kimani, D. (2011). Stock market performance and economic growth Empirical Evidence from Kenya using Causality Test Approach. Advances in Management and Applied Economics, 1(3), 177.

Osamwonyi, I. O., \& Kasimu, A. (2013). Stock market and economic growth in Ghana, Kenya and Nigeria. International Journal of Financial Research, 4(2), 83. 
Qamruzzaman, M., \& Wei, J. (2018). Financial innovation, stock market development, and economic growth: An application of ARDL model. International Journal of Financial Studies, 6(3), 69.

Rajabi, E., \& Muhammad, J. (2014). The stock markets, banks and growth nexus: Asian Islamic countries. Economic Notes: Review of Banking, Finance and Monetary Economics, 43(2), 137-165.

Rehman, M. Z. (2018). Banking sector development, stock market development and economic growth: Evidence from Saudi Arabia. Academy of Accounting and Financial Studies Journal, 22(4), 1-15.

Saibu, M. O., Bowale, K. E. I., \& Akinlo, A. E. (2009). Financial Structure and economic growth: empirical evidence from Nigeria. International Journal of Business and Emerging Markets, 1(3), 264-281.

Thorbecke, W. (1997). On stock market returns and monetary policy. The Journal of Finance, 52(2), 635654.

Ioannidis, C., \& Kontonikas, A. (2008). The impact of monetary policy on stock prices. Journal of policy modeling, 30(1), 33-53.

Zivengwa, T., Mashika, J., Bokosi, F. K., \& Makova, T. (2011). Stock market development and economic growth in Zimbabwe. International Journal of economics and Finance, 3(5), 140-150. 